UDC: 615.072:615.453:616.009

DOI: 10.15587/2519-4852.2017.119744

\title{
DEVELOPMENT OF COMPOSITION AND TECHNOLOGY OF COMBINATION DRUG WITH NEURALLY MEDIATED ACTION «MEMOFIT»
}

\author{
(C) O. Savelieva, I. Vladymyrova, T. Tishakova, O. Levashova
}

\begin{abstract}
Мета. Метою роботи було розробка складу комбінованого профілактичного засобу у вигляді твердих желатинових капсул «Мемофіт», визначення технологічних і мікробіологічних показників напівпродуктів і готової форми та розробка промислової технології капсул «Мемофіт».

Методи дослідження. Дослідження, представлені у статті, проводились за методиками, наведеними у Державній фармакопеї Украӥни.

Результати дослідження. У статті обгрунтована необхідність розробки добавки дієтичної до раціону харчування для надання спеціальних дієтичних властивостей з метою регуляиії функиій та систем організму в рамках фізіологічних норм при порушеннях функиій нервової системи. Представлено результати вивчення фармако-технологічних та мікробіологічних параметрів сухих екстрактів, що входять до складу твердих желатинових капсул «Мемофіт». Запропоновані оптимальні технологічні параметри виробництва капсул «Мемофіт». Представлені результати матеріального балансу серії капсул «Мемофіт», щуо підтверджують раціональність обраного технологічного процесу. Технологія виробництва капсул «Мемофіт» впроваджена в умовах ТОВ «ДЗ «ГНЦЛС».

Висновки. На основі отриманих експериментальних даних визначення фармако-технологічних показників сухих екстрактів було встановлено можливість розробки на їх основі твердих лікарських форм у вигляді капсул. Обтрунтована і розроблена промислова технологія і схема технологічного прочесу капсул «Мемофіт» для використання в раціонах дієтичного харчування як додаткове джерело біологічно активних речовин, щзо сприяе нормалізації функціонування головного мозку, підвищенню уваги, нормалізаціі сну; має загальнозміцнюючі властивості, підвищує розумову та фізичну працездатність
\end{abstract}

Ключові слова: технологія, тверді лікарські форми, капсули, рослинні екстракти, захворювання нервової системи

\section{Introduction}

Main diseases caused by stress give to understand that mental tension promotes not only negative emotions but also it intensifies chronic inflammatory processes at the different diseases. Physiological reactions occurring at the moment of inability to control yourself are the response of the organism on stress. Stress accompanies people from the origin of mankind only its causes can change in the course of time.

People who experience of stress are more inclined to the development of nervous system diseases. It has been affirmed that influence of stress on mental health is limited but destructiveness of stress was proved physiologically many times. Scientists could determine that stress is one of the most common causes of the development of different somatic diseases.

Many research of scientist prove that short-term single stress experience trains memory and brain making people to decide quickly. In this case human body triggers defense mechanism that assures rush of stress hormone promoting neuron interaction followed by improved efficiency of brain function. It is impossible to say how stress influences the memory and brain functions. Emotional instability and angst, anxiety, rueful feelings effect certain areas of brain that are responsible for memory, blocking which makes memory and intellectual abilities worse $[1,2]$.

2. Formulation of the problem in a general way, the relevance of the theme and its connection with important scientific and practical issues

Stress-relaxation practice, such as meditation, can improve your health and prevent memory loss. And, as it reduces some of the negative impacts of cholesterol, cortisol, and high blood pressure, a stress relaxation practice also has the added benefits of improving your focus, attention, and optimizing your overall mental performance. Biologically active substances, medicinal plants and herbal medicines can have sedative, anxiolytic properties and improve cerebral blood flow, physical and mental efficiency [3, 4].

3. Analysis of recent studies and publications in which a solution of the problem and which draws on the author

Treatment of neurological disorders must be comprehensive oriented to the removal of disease-related reasons and stress factor that can provoke them. To get positive effect in prevention, diagnosis and treatment of pathological conditions of nervous system is possible only by the influence on different components of pathological processes eliminating the cause of disease and symptomatology. According to this, medicinal plants and herbal medicines that have sedative, neuroprotective, tonic properties and raising nonspecific resistance of the organism are used $[5,6]$.

4. Allocation of unsolved parts of the general problem, which is dedicated to the article

Dietary supplements such as composition of natural (or nature-identical) biologically active substances intended to take with food or include into the composition of foods with the aim of fortification of ration with nutrient materials and biologically active substances and their complexes are an effective and harmless prophylactic agents. These supplements are products of plant, ani- 
mal and mineral origin that improve competition form, increase physical force, endurance, mental alertness and performance efficiency acting in the body more mildly then medicinal products and having much less adverse effects $[7,8]$.

Therefore, the development of combination domestic medicinal products based on the safe types of herbal raw materials facilitates the expansion of the range of dietary supplements used at the neurological disturbances and reverse after-effect of negative impact of stress.

Rational number of excipients necessary for carrying out of every production stage were calculated taking into account of physico-chemical properties of plant extracts. Microcrystalline cellulose (MCC) was added into the composition of capsules to improve encapsulation mass quality. Addition of lactose into the encapsulation mass enhances its physical characteristics because lactose has high stability and low hygroscopicity. One of the problems of capsule production is a formation of good fluidity of encapsulation mass in the electricpowered devices (hood, bunker). Received mass can have a rough surface that complicates its absorption from the filling hopper into the matrix slots. Besides that mass can stick during the encapsulation. Lubricant (magnesium stearate) was used for releasing and decreasing of these negative phenomena.

\section{Formulation of goals (tasks) of the article}

The aim of this article was the development of combination prophylactic agent in the form of hardgelatin capsules «Memofit», determination of technological and microbiological parameters of intermediate products and finished medicinal product and development of manufacturing process for capsule «Memofit».

6. Statement of the basic material of the study (methods and objects) with the justification of the results

Investigations focused on the active pharmaceutical ingredient or finished product production and determination of their technological and microbiological parameters were carried out on the TOV "DZ "GNCLS" facilities.
Dry extracts from ballota nigra herb and meadow rue pasque flower herb were obtained in accordance with general scheme. Air-dried dry raw material milled to the particle size 3-5 mm, were placed in extractor. Extraction was performed with hot water in the ratio raw material extractant 1:10 factored in absorption coefficient of extractant till complete extraction of BAA from the raw material. Extraction was done twice at the temperature 70 $80{ }^{\circ} \mathrm{C}$ for $1.5-2$ hours. Received extracts were combined, filtered and concentrated in vacuum evaporator at the temperature $50-60{ }^{\circ} \mathrm{C}$ and pressure $80-87 \mathrm{kPa}$ to obtain heavy consistence (humidity did not exceed $25 \%$ ). Obtained dry extracts were dried in the vacuum drying oven at the temperature $70-75{ }^{\circ} \mathrm{C}$ and pressure $80-87 \mathrm{kPa}$.

Dry extract from the leaves of ginkgo biloba was obtained by the extraction with $70 \%$ alcohol in the ratio raw material - extractant 1:5 factored in absorption coefficient of extractant till complete extraction of BAA.

Alcohol was distilled off from the received aqueous-alcoholic extract and dried at the above mentioned conditions.

Received dry extracts were monitored by the following quality parameters: appearance, loss on drying, heavy metals, microbiological quality according to the SPh Ukraine [9].

Received dry extracts are dark brown, free-flowing and non-hygroscopic powders with characteristic smell and taste common to plant raw material. Determined loss of drying for extracts of ballota nigra, meadow rue pasque flower and ginkgo biloba was $4.10 \%, 3.90 \%$ and $3.50 \%$, respectively. Content of heavy metals in dry extracts was not more than $0.01 \%$ (100 ppm). Loss on drying for obtained dry extracts did not exceed $5 \%$ in accordance with the requirements of SPh Ukraine [9].

Microbiological parameters for the active pharmaceutical ingredients used for production of dietary supplement are subject to the requirements of «Temporary hygienic norms for the contents of chemical and biological contaminants in the biologically active additives» No. TH 4.4.8.073-2001 [10]. Plating method was used to determine microbiological parameters [9]. Obtained results are given in the Table 1 below.

Table 1

Microbiological parameters for dry extracts and produced capsules

\begin{tabular}{|l|c|c|c|c|c|}
\hline \multirow{2}{*}{ Parameter } & Requirements of & \multicolumn{4}{c|}{ Results of monitoring* } \\
\cline { 3 - 6 } & AND & Sample № 1 & Sample № 2 & Sample № 3 & Sample № 4 \\
\hline TAMC (CFU g/mL) & $10^{4}$ & 260 & 320 & 450 & 490 \\
\hline TYMC (CFU g/mL) & $10^{2}$ & $<10$ & $<10$ & $<10$ & $<10$ \\
\hline Presence of & & & & \\
Enterobacteriaceae & absent & absent & absent & absent & absent \\
S. aureus & absent & absent & absent & absent & absent \\
P. aeruginosa & absent & absent & absent & absent & absent \\
\hline
\end{tabular}

Note: *sample № 1 is a dry extract of ginkgo biloba leaves, sample № 2 - dry extract from ballota nigra herb, sample № 3 - dry extract from meadow rue pasque flower herb, sample № 4 - «Memofit» capsules

Pharmaco-technological test for obtained dry extracts were performed in accordance with the procedures of SPh Ukraine. These tests included particle size distribution, fluidity that is characterized by the natural angle of slope and spilling time, bulk volume and volume after shrinkage, shrinkage qualities and density (bulk density and tapped density) [9].

Powders of obtained dry extracts were not nonhomogeneous on composition that's why sieve analysis was performed. It is known that particle size distribution 
of powders influences such technological properties of dry extracts as fluidity, pressing, density as well as organoleptic parameters, average mass of solid dosage forms, accuracy of dose for active substances in medicinal products $[11,12]$. Results of experimental data point to the fact that main fraction consists of powders with particle size from $0.2 \mathrm{~mm}$ to $0.31 \mathrm{~mm}$ for all extracts under test. This confirms ability to use these extracts to obtain dosage forms in the form of capsules because this fraction must have sufficient fluidity and density at the filling of capsule. Results of particle size distribution for obtained dry extracts are given in the Table 2.
Natural angle of slope changes in a wide range from 25 to $35^{\circ}$ for free-pouring and from 60 to $70^{\circ}$ for less-pouring materials. That's why the less natural angle of slope the more fluidity [11]. The values of natural angles of slope for dry extracts from the ballota nigra herb, meadow rue pasque flower herb and ginkgo biloba leaves were $29^{\circ}, 26^{\circ}, 27^{\circ}$, respectively. They are within the limits for free-pouring materials.

Results of bulk density determined during the manufacturing process were used to determine the volume of matrix channel $[11,12]$. Results of received parameters are given in the Table 3 .

Table 2

Particle size distribution of dry extracts

\begin{tabular}{|c|c|c|c|}
\hline \multirow{2}{*}{ Sieve size, mm } & \multicolumn{3}{|c|}{ Content of fraction, \% } \\
\cline { 2 - 4 } & $\begin{array}{l}\text { Dry extract of ballota } \\
\text { nigra herb }\end{array}$ & $\begin{array}{c}\text { Dry extract of meadow } \\
\text { rue pasque flower herb }\end{array}$ & $\begin{array}{l}\text { Dry extract of ginkgo } \\
\text { biloba leaves }\end{array}$ \\
\hline$-1.0+0.50$ & $13.51 \pm 0.04$ & $11.23 \pm 0.03$ & $10.12 \pm 0.04$ \\
\hline$-0.50+0.31$ & $13.02 \pm 0.04$ & $12.65 \pm 0.03$ & $13.89 \pm 0.04$ \\
\hline$-0.31+0.20$ & $60.25 \pm 0.03$ & $64.12 \pm 0.04$ & $63.47 \pm 0.03$ \\
\hline$-0.20+0.09$ & $10.69 \pm 0.03$ & $9.95 \pm 0.04$ & $10.58 \pm 0.03$ \\
\hline Screening & $2.53 \pm 0.03$ & $2.05 \pm 0.03$ & $1.95 \pm 0.03$ \\
\hline
\end{tabular}

Table 3

Pharmaco-technological parameters of dry extracts

\begin{tabular}{|l|c|c|c|}
\hline \multirow{2}{*}{ Pharmaco-technological parameters } & \multicolumn{2}{|c|}{ Results of determination } \\
\cline { 2 - 4 } & $\begin{array}{c}\text { Dry extract of ballota } \\
\text { nigra herb }\end{array}$ & $\begin{array}{c}\text { Dry extract of } \\
\text { meadow rue pasque } \\
\text { flower herb }\end{array}$ & $\begin{array}{c}\text { Dry extract of } \\
\text { ginkgo biloba } \\
\text { leaves }\end{array}$ \\
\hline $\begin{array}{l}\text { Bulk volume (volume before shrink- } \\
\text { age), ml }\end{array}$ & $104.00 \pm 1.49$ & $110.50 \pm 1.14$ & $139.50 \pm 1.26$ \\
Volume after shrinkage, ml & $85.50 \pm 0.75$ & $95.00 \pm 0.68$ & $118.50 \pm 0.85$ \\
Shrinkage capacity, ml & $18.50 \pm 0.61$ & $15.50 \pm 0.35$ & $21.00 \pm 1.21$ \\
\hline Bulk density, g/ml & $0.96 \pm 0.12$ & $0,91 \pm 0,10$ & $0.72 \pm 0.14$ \\
Tapped density, g/ml & $1.16 \pm 1.05$ & $1,05 \pm 0,45$ & $0.84 \pm 1.01$ \\
\hline Fluidity, sec & $12.09 \pm 0,23$ & $10.26 \pm 0.31$ & $18.59 \pm 0.24$ \\
- natural angle of slope, ${ }^{\circ}$ & $29.00 \pm 1.3$ & $26.00 \pm 1.22$ & $27.00 \pm 1.25$ \\
\hline
\end{tabular}

The composition of the solid dosage form in the form of gelatin capsules was developed basing on the obtained dry extracts, their investigation, as well as the results of the pharmacological action of the active pharmaceutical ingredients $[5,6,13]$.

The obtained solid gelatin capsules containing plant extracts had the following organoleptic characteristics. Description: homogeneous powder of plant origin from light brown to dark brown color. Smell. Specific due to the presence of plant material. Taste. Specific due to the presence of plant material.

During determination of the microbiological parameters of dry extracts and capsules on their basis, it was established the compliance of the investigated samples with requirements of TN 4.4.8.-072-2001. The results are presented in Table 3.

Composition of "Memofit" capsules (composition of 1 capsule):

Dry extract of ginkgo biloba leaves

Dry extract of the ballota nigra herb

Dry extract of meadow rue pasque flower herb

Lecithin

Choline bitartrate

Excipients:

Microcrystalline cellulose, lactose,

calcium stearate (magnesium)

The manufacturing of capsules was carried out according to the general technological scheme. The active ingredients and excipients in the solid state in the form of powder were filled into one of the parts of the

$$
\begin{aligned}
& 40.0 \mathrm{mg} \\
& 50.0 \mathrm{mg} \\
& 20.0 \mathrm{mg} \\
& 140.0 \mathrm{mg} \\
& 50.0 \mathrm{mg} \\
& \text { up to } 500,0 \mathrm{mg}
\end{aligned}
$$

shell, which was tightly closed by the second part. Solid capsules have a shell consisting of two prefabricated parts of a cylindrical shape, one end of each part is rounded and closed, and the other end is open [4]. 
Based on the obtained experimental data, it became possible to develop an industrial technology for obtaining the product and implement it in the production in TOV "DZ "GNCLS". The scheme of technological process of capsules "Memofit" production in industrial conditions is shown on Fig. 1.

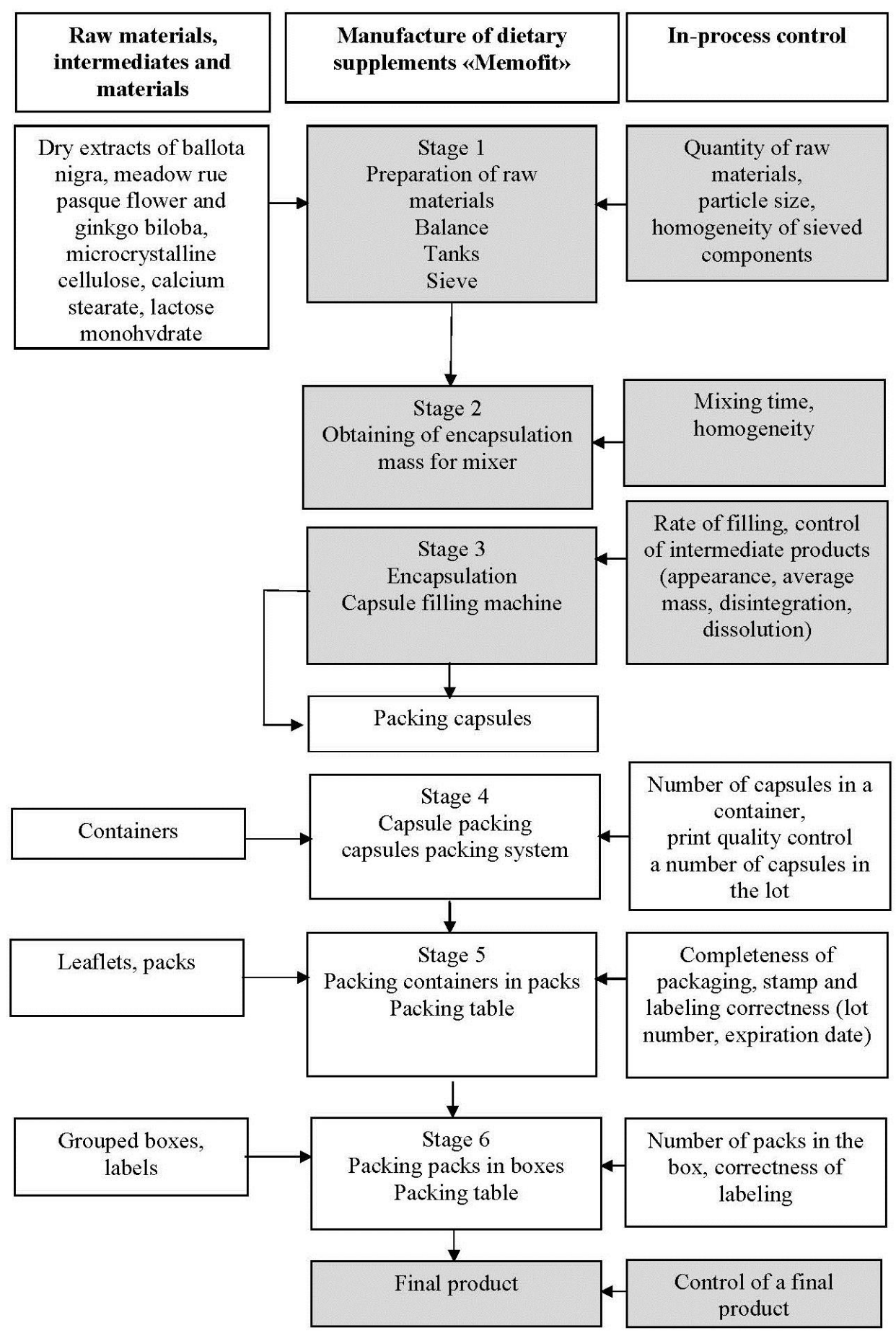

Fig. 1. Scheme of production of solid gelatinous capsules "Memofit"

Stage 1. Preparation of raw materials

It begins with the receipt of raw materials from the warehouse. Each lot (batch) of a dry extract of ballota nigra, meadow rue pasque flower and ginkgo biloba, microcrystalline cellulose, calcium stearate and lactose monohydrate (80) coming into production, regardless of the presence of a supplier certificate, is to be checked at the control and analytical laboratory on compliance with the requirements of the current analytical normative documentation (AND).
The raw materials are used in the production after receiving the analytical passport from the analytical laboratory, which confirms its quality.

The ingredients for the lot are weighed in tared, labeled tank on scales (CP 7). Sieve the ingredients on the manual sieve № $250(0.250 \pm 0.034 \mathrm{~mm})$ (GF 4) in the tared tanks (C 6.1.-C 6.5.).

Control the quality of screening - the absence of visible particulate matter in the screened raw material. 
Stage 2. Obtaining mass for encapsulation

All ingredients from the tanks (C 6.1.-C 6.5.) are transferred into the mixer (GF 18) and mix. Transfer the mass from the mixer (GF 18) in the tank (C 21) through the sieve number $250(0.250 \pm 0.034 \mathrm{~mm})(\mathrm{GF} 4)$.

Stage 3. Encapsulation and dedusting of capsules

Encapsulation of mass from stage 2 is carried out on an encapsulator MS-2. Hard-gelatin capsules number 1 are obtained. Weigh the mass for encapsulation on the sheet of paper in order to fill 120 capsules on scales (CP 2). Conduct the filling of the first 120 capsules. After filling the first capsules, control the average mass of one capsule $0.500 \mathrm{~g} \pm 7.5 \%$ (from 0.4815 to $0.5006 \mathrm{~g}$ ). When positive results of the average mass are obtained, the prepared amount of mass is encapsulated.

Filled capsules are controlled for the absence of mechanical damages and various deformations.

Dedusting of capsules is carried out in the fume hood by shaking capsules on a metal hand-screen № 50 .
Stage 4. Pre-packing of capsules

Capsule packing is carried out on a capsule filling system (GF 55) by 50 capsules in containers sealed with a tamper-evident closure. Free space in a container or a bottle is filled with hygroscopic medical cotton.

The label or self-adhesive label is attached to the container or bottle.

\section{Stage 5. Packing of capsules}

Each tamper-evident capped container is placed in a pack of imported cardboard «Alaska GS-2», manufactured by the company «International Paper - Kwidzyn s.a.», Poland or from the recycle cardboard chromeersatz in accordance with TU U 13-0281041-315-96.

70 packs are put into corrugated box number 7 .

In order to determine the correctness of the choice, organization of the technological process and the development of production regulations, the mass balance was calculated for the production of the dietary supplement "Memofit"; it presented in Table 4.

Table 4

Mass balance of a lot

\begin{tabular}{|c|c|c|c|c|c|}
\hline \multicolumn{3}{|c|}{ Consumed } & \multicolumn{3}{|c|}{ Received } \\
\hline \multirow{2}{*}{$\begin{array}{c}\text { Name of raw material, } \\
\text { intermediates and } \\
\text { materials }\end{array}$} & \multicolumn{2}{|c|}{ Quantity } & \multirow{2}{*}{$\begin{array}{l}\text { Name of final product, } \\
\text { losses and waste }\end{array}$} & \multicolumn{2}{|c|}{ Quantity } \\
\hline & kg & t. units & & kg & t. units \\
\hline Raw materials & & & 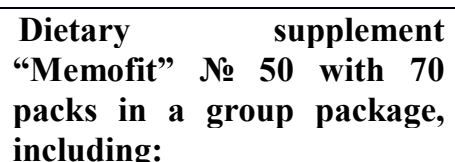 & 25.0 & \\
\hline $\begin{array}{l}\text { Dry extract of the ballota } \\
\text { nigra herb }\end{array}$ & 2.625 & & $\begin{array}{l}\text { Hard-gelatin capsules № } 0 \text {, } \\
\text { red-white }\end{array}$ & & 50.0 \\
\hline $\begin{array}{l}\text { Dry extract of meadow rue } \\
\text { pasque flower herb }\end{array}$ & 1.05 & & Containers or bottles & & 1.000 \\
\hline $\begin{array}{l}\text { Dry extract of ginkgo } \\
\text { biloba leaves }\end{array}$ & 2.1 & & Self-adhesive labels & & 1.000 \\
\hline Lecithin & 7.35 & & Pack & & 1.000 \\
\hline Choline bitartrate & 2.625 & & Leaflet & & 1.000 \\
\hline Microcrystalline cellulose & 7.875 & & Corrugated box № 7 & & 0.015 \\
\hline Lactose & 2.362 & & Pads to corrugated box № 7 & & 0.03 \\
\hline Calcium stearate & 0.263 & & Group labels & & 0.015 \\
\hline $\begin{array}{l}\text { Hard-gelatin capsules № } 0 \text {, } \\
\text { red-white }\end{array}$ & & 52.0 & $\begin{array}{l}\text { Self-adhesive tape or packing } \\
\text { tape (scotch tape) }\end{array}$ & & 0.3 \\
\hline & & & Wastes, including: & & \\
\hline Materials & & & Containers or bottles & & 0.005 \\
\hline Containers or bottles & & 1.005 & Self-adhesive labels & & 0.005 \\
\hline Self-adhesive labels & & 1.005 & Pack & & 0.005 \\
\hline Pack & & 1.005 & Leaflet & & 0.005 \\
\hline Leaflet & & 1.005 & Group labels & & 0.003 \\
\hline Corrugated box № 7 & & 0.015 & & & \\
\hline $\begin{array}{l}\text { Pads to corrugated box № } \\
7\end{array}$ & & 0.030 & & & \\
\hline Group labels & & 0.018 & & & \\
\hline $\begin{array}{l}\text { Self-adhesive tape or } \\
\text { packing tape (scotch tape) }\end{array}$ & & 0.0003 & & & \\
\hline & & & Expenses: & & \\
\hline & & & Encapsulation mass & 1.25 & \\
\hline & & & $\begin{array}{l}\text { Hard-gelatin capsules № } 0 \text {, } \\
\text { red-white }\end{array}$ & & 2.0 \\
\hline Total & 26.25 & $\mathbf{5 6 . 0 8 3 3}$ & Total & 26.25 & 56.0833 \\
\hline
\end{tabular}


Manufacturing specification was developed based on the obtained mass balance data and the level of the technological process organization was assessed as sufficiently effective. The mass balance allowed to calculate the general technical and economic indexes of production such as the regulated expenditure rates of raw materials, materials, intermediate products and energy per unit of finished product.

Determination of quality parameters of the finished dosage form: organoleptic parameters, mass homogeneity (2.9.5), decomposition (2.9.3) were performed according to the $\mathrm{SPhU}$ procedure in order to develop the technical specifications of Ukraine for the dietary supplement "Memofit" [9].

The uniformity of mass was determined for 20 units of a dosage form of medicinal product, selected by a statistically valid scheme, weighed each separately and calculated the average mass. A medicinal product can passes the test if no more than two individual masses deviate from a value that does not exceed the value specified in Table. 2.9.5.-1. For capsules with an average mass of $300 \mathrm{mg}$ or more, the tolerable deviation is $7.5 \%$ [9]. formula:

The average capsule mass was calculated by the

$$
m_{c p}=\frac{\sum x_{i}}{X_{i}},
$$

where $\Sigma \mathrm{x}_{\mathrm{i}}$-sum of the masses of 20 capsules, $\mathrm{g} ; \mathrm{X}_{\mathrm{i}}-$ quantity of capsules.

The maximum deviation from the average mass was calculated by the formula:

$$
X=\frac{X_{\max }-m_{c p}}{m_{c p}} \cdot 100 \%,
$$

where $\mathrm{X}_{\max }$ - the maximum value of the capsule mass, $\mathrm{g}$; $\mathrm{m}_{\mathrm{av}}$ - an average capsule mass, $\mathrm{g}$.

The minimum deviation from the average mass was calculated by the formula:

$$
X=\frac{X_{\min }-m_{c p}}{m_{c p}} \cdot 100 \%,
$$

where $X_{\min }$ - the minimum value of the capsule mass, $g$; $\mathrm{m}_{\mathrm{av}}$ - an average capsule mass, $\mathrm{g}$.

The following experimental data were obtained during determination the of the uniformity of mass of capsules: the average mass $0.4493 \mathrm{~g}$, the maximum deviation from the average mass $1.27 \%$, the minimum deviation from the average mass $2.59 \%$. The obtained data meets the requirements of the $\mathrm{SPhU}$ regarding the quality of hard-gelatin capsules.

Water was used as a liquid medium for disintegration tests. The device was switched on for 30 minutes maintaining the temperature at $36-38{ }^{\circ} \mathrm{C}$ and examined the state of the capsules. Tests are considered to be sustained if all six capsules disintegrate. The conducted "Disintegration of tablets and capsules" test showed that solid capsules with dry extracts disintegrate in 1520 minutes.

\section{Findings from the research and prospects of further development of this area}

The results of the development of the composition of the combination prophylactic agent in the form of hard-gelatin capsules «Memofit», determination of technological and microbiological parameters of intermediate products and finished medicinal product and development of manufacturing process for capsule «Memofit» are presented.

Pharmaco-technological and microbiological parameters of dry extracts, included in the composition of hard-gelatin capsules "Memofit" were studied. Research of rational composition choice and optimal technological parameters for production of capsules "Memofit" was carried out. The results of the mass balance for the lot of capsules "Memofit" that confirm the rationality of the chosen technological process are presented. The technology of manufacturing process for capsules "Memofit" was introduced in the production in TOV "DZ "GNCLS".

Developed capsules "Memofit" proposed for use in diets as additional source of biologically active substances that promotes normalization of brain functioning, increase of attention, normalize sleep cycle; having tonic properties, raises mental and physical efficiency.

\section{References}

1. Voznesenskaya, T. G. Emotional stress and prevention of its consequences [Text] / T. G. Voznesenskaya // RMJ. - 2008. Vol. 14, Issue 9. - P. 694-697.

2. Vorobyova, O. V. Stress and Adaptation Disorders [Text] / O. V. Vorobyova // RMJ. - 2009. - Vol. 17, Issue 11. P. 789-793.

3. Avdeyeva, T. I. Herbal preparations in the treatment of anxiety disorders [Text] / T. I. Avdeyeva, M. A. Kinkulkina // Doctor. - 2008. - Issue 11. - P. 49-52.

4. Grechany, I. A. Great illustrated guide to medicinal herbs and plants. 600 recipes and secrets of the hereditary herbalist [Text] / I. A. Grechany. - Kharkiv: Book Club "Family Leisure Club", 2015. - 544 p.

5. Mosyakin, S. L. Vascular plants of Ukraine: a nomenclatural checklist [Text] / S. L. Mosyakin, M. M. Fedoronchuk. Kyiv: National Academy of Sciences of Ukraine, M. G. Kholodny Institute of Botany, 1999. - 345 p.

6. Borovikov, V. S. Useful species of the genus THALICTRUM L. (Meadowrue) Altai mountain country [Text] / V. S. Borovikov // Vestnik Altai State University. - 2011. - Issue 1 (75). - P. 32-34.

7. Vrchovska, V. Antioxidative properties and phytochemical composition of Ballota nigra infusion [Text] / V. Vrchovska, J. Spilkova, P. Valentao, C. Sousa, P. B. Andrade, R. M. Seabra // Food Chemistry. - 2007. - Vol. 105, Issue 4. - P. 1396-1403. doi: 10.1016/j.foodchem.2007.05.016

8. Bylka, W. Stan badan nad zielem mierznicy czarnej (Ballotae nigrae herba) [Text] / W. Bylka, E. Studzinska-Sroka, P. Znajdek-Awizen // Postepy Fitoterapii. - 2014. - Issue 3. - P. 180-183.

9. Dezhi, F. Thalictrum L [Text] / F. Dezhi, Z. Guanghua // Flora of China. - 2011. - Vol. 6. - P. 282-302.

10. State Pharmacopoeia of Ukraine [Text]. - Kharkiv: REEREG, 2001. - 556 p. 
11. "Temporary hygienic norms of the content of chemical and biological contaminants Nature in Biologically Active Additives "ГН 4.4.8.073-2001: Resolution Chief Sanitary Doctor of Ukraine dated April 20, 2001 [Text]. - Official bulletin Of Ukraine. - 2001. - Vol. 131. - P. 316-332.

12. Chudeshov, V. I. Technology of medicines for industrial production [Text] / V. I. Chudeshov, L. M. Khokhlova, O. O. Lyapunov et. al.; V. I. Chueshov (Ed.). - Kharkiv: Publishing NUPh "Golden pages", 2003. - 720 p.

13. Shteyngardt, M. V. Solid dosage forms [Text]: Coll. sci. paper. / M. V. Steinhardt, N. A. Kazarinov // Technology and standardization of drugs. - Kharkiv: LLC «Reereg», 1996. - P. 539-605.

14. Savelieva, E. V. Determination of effect of Ballota nigra extract on the state of lipid peroxidation and rats' antioxidant system under chronic immobilization stress [Text] / E. V. Savelieva, I. N. Vladymyrova, T. S. Tishakova // Der Pharmacia Lettre. 2016. - Vol. 8, Issue 5. - P. 227-230.

Дата надходження рукопису 27.10.2017

Elena Savelieva, Department of Medical and Bioorganic Chemistry, Kharkiv National Medical University, Nauky ave., 4, Kharkiv, Ukraine, 61022

E-mail: elena_s12@ukr.net

Inna Vladymyrova, Doctor of Pharmaceutical Sciences, Associate Professor, Department of Pharmacognosy National University of Pharmacy, Pushkinska str., 53, Kharkiv, Ukraine, 61002

E-mail: inna.vladimirova2015@gmail.com

Tatyana Tishakova, PhD, Department of Medical and Bioorganic Chemistry, Kharkiv National Medical University, Nauky ave., 4, Kharkiv, Ukraine, 61022

E-mail: ttishakova@ukr.net

Olga Levashova, PhD, Department of Medical and Bioorganic Chemistry, Kharkiv National Medical University Nauky ave., 4, Kharkiv, Ukraine, 61022

E-mail: olga.jdan78@gmail.com

УДК: 615.454.124.014.23 : 615.28

DOI: $10.15587 / 2519-4852.2017 .119890$

\title{
SUBSTANTIATION OF THE COMPOSITION OF SURFACE-ACTIVE SUBSTANCES IN DEVELOPMENT OF A CREAM WITH SILVER CITRATE
}

\author{
(C) Z. Polova, I. Gladukh, H. Kukhtenko
}

Фармацевтичним емульсіям нині приділяється все більша увага, оскільки вони нашли широке застосування в медичній практииі. Це стало можливим завдяки якісно новому рівню наукових досліджень та досягнень в області створення емульсійних систем, а також розширенню асортименту допоміжнх речовин та використанню нового сучасного обладнання. Емульсї являють собою гетерогенні дисперсні системи, щзо потенційно нестабільні. Тому питання стабілізації емульсійних систем є головним в технологї емульсій.

Мета. Вивчення структурно-механічних властивостей концентрованих емульсійних систем в залежності від сумарної концентрачї ПАР та дослідження колоїдної та термічної стабільності зразків для обгрунтування складу поверхнево-активних речовин при розробиі крему з срібла ицитратом.

Методи. Фармако-технологічні методи досліджень проводили згідно з вимогами Державної Фармакопеї України.

Результати дослідження. Досліджено колоїдну та термічну стабільність зразків крему емульсійного з срібла цитратом, за якими встановлено, що використання емульгаторів в концентрації $4 \%$ та $6 \%$ не забезпечує фізичної стабільності. Виконано дисперсний аналіз гетерогенних систем, за якими встановлено, щчо зразки із використанням комбінації емульгаторів є однорідними за розміром частинок масляної фази, які не перевищують 10 мкм. Досліджено поведінку зразків емульсійного крему з срібла иитратом під час та після механічної деструкиії, результати яких гарантують стабільність системи під впливом механічної обробки в процесі промислового виробниџтва та використання.

Висновки. В результаті експерименту обтрунтовано використання для стабілізації емульсійної системи з срібла ичитратом комбінацію поверхнево-активних речовин: емульгатор № 1 та цетостеариловий спирту у кількості 8-10\%

Ключові слова: емульсійна система, поверхнево-активні речовини, крем, цитрат срібла, стабільність 